
VOLUME 10 NOMOR 4 AGUSTUS 2021

ISSN : 2303-1514 | E-ISSN : 2598-5949

DOI : http://dx.doi.org/10.33578/jpfkip.v10i4.8258

https://primary.ejournal.unri.ac.id/index.php/JPFKIP

\title{
THE EFFECT OF SCOUTING EXTRACURRICULAR ON STUDENTS' DISCIPLINE AT SD NEGERI 4 ABUAN SUSUT DISTRICT, BANGLI REGENCY
}

\author{
I Nyoman Sudirman ${ }^{1}$, I Wayan Numertayasa ${ }^{2}$, I Wayan Rendana ${ }^{3}$ \\ ${ }^{1,2,3}$ STKIP Suar Bangli, Bangli, Indonesia \\ ${ }^{1}$ putrateacher@gmail.com, ${ }^{2}$ numertayasawayan@gmail.com, ${ }^{3}$ rendana.22@gmail.com
PENGARUH EKSTRAKURIKULER KEPRAMUKAAN TERHADAP KEDISIPLINAN SISWA SD NEGERI 4 ABUAN KECAMATAN SUSUT KABUPATEN BANGLI

\begin{tabular}{|c|c|}
\hline ARTICLE HISTORY & ABSTRACT \\
\hline $\begin{array}{l}\text { Submitted: } \\
23 \text { Maret } 2021 \\
23^{\text {th }} \text { March } 2021\end{array}$ & $\begin{array}{l}\text { Abstract: This research focused on the effect of scouting extracurricular on the students' } \\
\text { discipline at SDN } 4 \text { Abuan. The subjects in this study were } 25 \text { students of SD Negeri } 4 \text { Abuan. } \\
\text { Data were obtained through a questionnaire. Then, the data were analyzed by the correlation } \\
\text { analysis of causal relationships with SPSS (Statistical Package For Social Science) version } \\
25.0 \text { and the results of the analysis were quantitative scores. The results obtained that scouting } \\
\text { extracurricular significantly influenced the students' discipline at SD Negeri } 4 \text { Abuan, } \\
\text { Kecamatan Susut, Kabupaten Bangli. This conclusion was supported by the average score } \\
\text { obtained from the students which were } 80.13 \text { and } 81.30 \text { (Excellent). In addition, it was found } \\
\text { that the influence of scouting extracurricular on students' discipline had a positive and } \\
\text { significant effect. This was indicated by the correlation coefficient for } 0.925 \text { or } 92.5 \% \text { meaning } \\
\text { that the score was at an interval of } 0.80-1.00 \text {. Thus, there was a very strong influence between } \\
\text { variable X (Extracurricular Scout) and } Y \text { (Student Discipline) and the results of the test results } \\
\text { (sig. 2-tailed (0.05)) resulted in a figure of } 0,000 \text { so that this number was less than the } \\
\text { significance value of } 0.05 \text { ( } 0,000<0.005) \text {. this indicated that there was a positive and } \\
\text { significant effect between the two variables. Based on the results of the correlation coefficient } \\
\text { (R) data analysis, simple linear regression analysis and the significance test (T test), it was } \\
\text { concluded that the extracurricular positively and significantly influenced the students' } \\
\text { discipline at SD Negeri } 4 \text { Abuan, Kecamatan Susut, Kabupaten Bangli. }\end{array}$ \\
\hline
\end{tabular}

Accepted:

06 Agustus 2021

$06^{\text {th }}$ August 2021

Keywords: scouting extracurricular, students' discipline

\begin{abstract}
Abstrak: Penelitian ini difokuskan pada permasalahan pengaruh ekstrakurikuler kepramukaan terhadap kedisiplinan siswa sd negeri 4 abuan. Subjek dalam penelitian ini yaitu 25 siswa SD Negeri 4 Abuan. Data diperoleh dengan menggunakan angket/kuisioner. Teknik analisis dalam penelitian ini dengan analisis korelasi hubungan kausal dengan program SPSS (Statistical Package For Social Science) versi 25.0 dan hasil analisis berupa skor secara kuantitatif. Hasil yang diperoleh dalam penelitian ini adalah ekstrakurikuler pramuka berpengaruh signifikan terhadap kedisiplinan siswa SD Negeri 4 Abuan Kecamatan Susut Kabupaten Bangli. Simpulan ini didukung oleh hasil skor rata-rata yang diperoleh siswa sebesar 80.13 dan 81.30 yang termasuk ke dalam kategori sangat baik. Selain itu diperoleh bahwa pengaruh ekstrakurikuler kepramukaan terhadap kedisilinan siswa memiliki pengaruh yang positif dan signifikan. Ini ditunjukan oleh koefisien korelasi sebesar 0.925 atau $92.5 \%$ yang berarti skor berada pada interval 0.80-1.00. Berarti terdapat pengaruh yang sangat kuat antara variabel X (Ekstrakurikuler Pramuka) dan Y (Kedisiplinan Siswa). Serta dengan hasil hasil uji (sig. 2-tailed (0.05)) menghasilkan angka yaitu 0.000 Sehingga angka ini kurang dari nilai signifikansi yaitu $0.05(0.000<0.005)$, yang berarti terjadi pengaruh yang positif dan signifikan antara kedua variabel. Jadi berdasarkan hasil analisis data koefesien korelasi $(R)$, analisis regresi linear sederhana dan uji signifikansi (Uji T) yang dihasilkan, dapat disimpulkan bahwa terjadi pengaruh yang positif dan signifikan antara ekstrakurikuler dan kedisiplinan siswa SD Negeri 4 Abuan Kecamatan Susut Kabupaten Bangli.
\end{abstract}

Published:

25 Agustus 2021

Kata Kunci : ekstrakurikuler pramuka, kedisiplinan siswa

CITATION

Sudirman, I. N., Numertayasa, I. W., \& Rendana, I. W. (2021). The Effect of Scouting Extracurricular on Students' Discipline at SD Negeri 4 Abuan Susut District, Bangli Regency. Primary: Jurnal Pendidikan Guru Sekolah Dasar, $10 \quad$ (4), 818-828. DOI: http://dx.doi.org/10.33578/jpfkip.v10i4.8258. 


\section{PENDAHULUAN}

Sekolah merupakan wahana yang menyediakan tempat terbaik bagi generasi muda penerus bangsa untuk menjadi lebih baik dalam berbagai aspek yang dapat memperkecil dan mengurangi penyebab berbagai masalah budaya dan karakter bangsa. Nilai-nilai karakter yang dikembangkan di sekolah yaitu: 1) Religius; 2) Jujur; 3) Bertanggung jawab; 4) Bergaya hidup sehat; 5) Disiplin; 6) Kerja keras; 7) Percaya diri; 8) Berjiwa wirausaha; 9) Berfikir logis, kritis, kreatif, dan inovatif; 10) Mandiri; 11) Ingin tahu; 12) Cinta ilmu; 13) Sadar hak dan kewajiban diri dan orang lain 14) Patuh pada aturan nasional; 15) Menghargai karya dan prestasi orang lain; 16) Santun; 17) Demokratis; 18) Nasionalis; 19) Menghargai keberagaman (Gunawan, 2014: 33). Dalam pelaksanaannya di sekolah penanaman nilai-nilai karakter dapat dilaksanakan secara terpadu melalui pembelajaran di kelas, maupun melalui kegiatan ekstrakurikuler yang ada di sekolah. Ada beberapa ekstrakurikuler yang diadakan di SD Negeri 4 Abuan, meliputi ekstrakurikuler kepramukaan, seni tari, seni tabuh, tenis meja, permaian catur, mesatua bali dan nyastra bali.

Salah satu program sekolah yang dapat menumbuh kembangkan keterampilan dan kedisiplinan siswa menurut peneliti adalah melalui ekstrakurikuler kepramukaan. Menurut Aqib (2015: 59) kegiatan ekstrakurikuler bertujuan untuk mendukung dan mengembangkan kompetensi akademik, bakat, minat, dan kepribadian maupun karakter. Ekstrakurikuler kepramukaan merupakan ekstrakurikuler yang wajib diikuti oleh para siswa. Pada hakikatnya pramuka dikelola oleh Gerakan Pramuka seperti tertuang dalam Pasal 5 Keppres No. 24 Tahun 2009 menyatakan "Gerakan Pramuka mempunyai tugas pokok menyelenggarakan kepramukaan bagi kaum muda guna menumbuhkan tunas bangsa agar menjadi generasi yang lebih baik, bertanggungjawab, mampu membina dan mengisi kemerdekaan nasional serta membangun dunia lebih baik".
Kepramukaan merupakan proses pendidikan di luar lingkungan sekolah dan di luar lingkungan keluarga dalam bentuk kegiatan menarik, menyenangkan, sehat, teratur, terarah, dan praktis, dilakukan di alam terbuka dengan sasaran akhirnya adalah pembentukan watak, akhlak, dan budi pekerti luhur (Gunawan, 2014: 265). Berdasarkan pernyataan tersebut, ektrakurikuler kepramukaan merupakan salah satu program sekolah yang tepat menurut peneliti untuk penanaman karakter kepada siswa yang salah satunya adalah karakter disiplin.

SD Negeri 4 Abuan mempunyai beberapa aturan yang harus ditaati oleh seluruh siswa untuk menegakkan disiplin. Aturan tersebut antara lain; (1) Datang tepat waktu (07:00 pagi), (2) Berpakaian rapi sesuai dengan hari yang sudah ditentukan, (3) Membiasakan membersihkan kamar mandi dan halaman sekolah, (4) Melaksanakan tugas piket kelas, (5) Menyelesaikan tugas yang diberikan sesuai dengan ketentuan yang berlaku, (6) Ikut menjaga ketenangan belajar baik di kelas, perpustakaan, maupun di lingkungan sekolah, (7) Bersikap sopan, santun, dan menghargai terhadap semua warga sekolah, (8) Membiasakan membuang sampah pada tempatnya, (9) Ikut menjaga $7 \mathrm{k}$ ( kebersihan, keindahan, keamanan, ketertiban, kekeluargaan, kerindangan, dan kenyamanan), (Suber Tata Tertib Kelas SD Negeri 4 Abuan)

Berdasarkan observasi di SD Negri 4 Abuan pada 6 Januari sampai 7 Maret 2020 tentang ekstrakurikuler kepramukaan yang dilaksanakan seminggu sekali pada hari Sabtu kurang memberikan pengaruh pada pembentukan karakter siswa di sekolah. Permasalahan yang sangat menonjol terlihat pada kedisiplinan siswa, permasalahan tersebut antara lain: (1) siswa datang terlambat, (2) tidak membawa pulang buku pelajaran dan alat sekolah, (3) tidak menyelesaikan tugas tepat waktu, (4) tidak memperhatikan pelajaran, (5) membuang sampah tidak pada tempatnya, (6) berpakaian tidak rapi. Realita di lapangan menunjukkan bahwa belum tertanamnya sikap kedisiplinan pada diri siswa. 
Berdasarkan masalah yang telah dipaparkan di atas, maka peneliti terdorong untuk melakukan pengkajian terhadap permasalahan tersebut dengan berfokus pada ekstrakurikuler pramuka dan kedisiplinan siswa. Ekstrakurikuler pramuka yang dimaksud dalam penelitian ini yakni pengaruh ekstrakurikuler terhadap kedisiplinan siswa.

Penelitian ini akan dilaksanakan di SD

Negeri 4 Abuan dengan pertimbangan bahwa sekolah tersebut merupakan salah satu sekolah di Bangli yang berstatus SD Negeri dengan jumlah siswa yang sangat minin setiap kelasnya dan bahkan jumlah keseluruhannya masih dibawah 100 siswa, namun keadaan dan situasi siswa sangat rendah sekali tingkat kedisiplinannya.

Alasan lain memilih SD Negeri 4 Abuan sebagai lokasi penelitian selain karena peneliti kebetulan bertugas/bekerja di SD Negeri 4 Abuan sebagai pegawai, dan juga sebagai salah satu pembina pramuka. Peneliti mengetahui secara langsung tingkat kedisiplinan siswa SD Negeri 4 Abuan masih sangat rendah sekali, yang paling menonjol sekali yaitu kelas satu baru, karena peralihan dari situasi TK ke SD sangat nampak sekali siswa-siswi tersebut sangat kurang sekali tingkat kedisiplinannya, masih terbawa suasana di TK yang mana masih terlalu dimanja baik oleh orang tua maupun guru TK nya, sehingga sangat perlu sekali pendidikan karakter diterapkan, salah satunya yaitu dengan ekstrakurikuler pramuka. Adanya fenomena tersebut, maka peneliti tertarik untuk mengetahui ada tidaknya pengaruh ekstrakurikuler kepramukaan terhadap kedisiplinan siswa, dan mengetahui seberapa besar pengaruh ekstrakurikuler kepramukaan terhadap kedisiplinan siswa khususnya pada SD Negeri 4 Abuan.

\section{KAJIAN TEORI}

Gerakan Pramuka Indonesia adalah nama organisasi pendidikan nonformal yang menyelenggarakan pendidikan kepanduan yang dilaksanakan di Indonesia. Pramuka merupakan bagi anggota Gerakan Pramuka yang meliputi Pramuka Siaga, Pramuka Penggalang, Pramuka Penegak, dan Pramuka Pandega. Ekstrakurikuler kepramukaan diselenggarakan oleh gerakan pramuka bermaksud untuk mempersiapkan generasi muda sebagai calon pemimpin bangsa yang memiliki watak, kepribadian, dan akhlak mulia serta keterampilan hidup prima. Kegiatan pendidikan kepramukaan dilaksanakan melalui Gugus depan Gerakan Pramuka yang berpangkalan di sekolah dengan upaya pembinaan melalui proses kegiatan belajar dan mengajar di sekolah. Melalui pendidikan kepramukaan dapat dilakukan pembinaan ketakwaan terhadap Tuhan Yang Maha Esa, kehidupan berbangsa dan bernegara berdasarkan Pancasila, pendidikan pendahuluan bela negara, kepribadian dan budi pekerti luhur, berorganisasi, pendidikan kewiraswastaan, kesegaran jasmani, daya kreasi, persepsi, apresiasi dan kreasi seni, tenggang rasa serta kerjasama (Gunawan, 2014: 265). Kepramukaan pada hakekatnya adalah (1) Suatu proses pendidikan dalam bentuk kegiatan yang menyenangkan bagi anak dan pemuda di bawah tanggungjawab orang dewasa; (2) Dilaksanakan di luar jam belajar kurikulum standar, di luar lingkungan pendidikan keluarga dan di alam terbuka; (3) Menggunakan prinsip dasar kepramukaan (Rahmatia, 2015: 5). Asmani (2013: 35) berpendapat bahwa pendidikan karakter merupakan upaya-upaya yang dirancang dan dilaksanakan secara sistematis untuk membantu siswa memahami nilai-nilai perilaku manusia yang berhubungan dengan Tuhan Yang Maha Esa, diri sendiri, sesama manusia, lingkungan, dan kebangsaan. Kemudian, nilai-nilai tersebut terwujud dalam pikiran, sikap, perasaan, perkataan, dan perbuatan berdasarkan norma-norma agama, hukum, tata krama, budaya, dan adat istiadat.

Disiplin merupakan tindakan yang menunjukkan perilaku tertib dan patuh pada berbagai ketentuan dan peraturan (Asmani, 2013: 37). Pendapat yang sama di kemukakan oleh Daryanto (2013: 49) bahwa disiplin pada dasarnya merupakan control diri dalam 
mematuhi aturan baik yang dibuat oleh diri sendiri maupun diluar diri baik keluarga, lembaga pendidikan, masyarakat, bernegara maupun beragaman. Disiplin merujuk pada kebebasan individu untuk tidak bergantung pada orang lain dalam memilih, membuat keputusan, tujuan, melakukan perubahan perilaku, pikiran maupun emosi sesuai aturan moral yang dianut. Gunawan (2014: 241) menjelaskan bahwa disiplin mengharuskan setiap individu untuk selalu taat asas, patuh, dan konsisten terhadap aturan yang dibuat dan disepakati bersama, serta tercermin dalam nilai-nilai kukuh hati, menghargai waktu, dan berani berbuat benar. Sedangkan Wiyani (2014: 160) berpendapat bahwa disiplin adalah upaya yang dilakukan oleh guru untuk menjadikan siswa memiliki kemampuan guna mengendalikan diri dan berperilaku sesuai dengan tata tertib. Jadi kedisiplinan yang dilakukan merupakan perwujudan dari sikap dan tindakan kukuh pada tata tertib atau aturan-aturan di sekolah dan menghargai waktu, karena terdorong oleh semangat berani berbuat benar dan bukan faktor takut terhadap sanksi.

\section{METODE PENELITIAN}

Jenis penelitian yang digunakan adalah pendekatan kuantitatif dengan menggunakan jenis penelitian korelasi hubungan kausal. Menurut Sugiyono (2011: 59) hubungan kausal adalah hubungan yang bersifat sebab akibat. Korelasi hubungan kausal merupakan korelasi antara dua variabel, variabel yang satu mempengaruhi variabel yang lain. Terdapat variabel independen (variabel yang mempengaruhi) dan variabel dependen (variabel yang dipengaruhi). Penelitian ini bertujuan untuk mengetahui pengaruh ekstrakurikuler kepramukaan terhadap kedisiplinan siswa. Subjek dalam penelitian ini adalah siswa SD Negeri 4 Abuan yang terdiri dari kelas II, kelas III dan kelas IV dengan jumlah 25 siswa. Sedangkan objek dalam penelitian ini adalah pengaruh ekstrakurikuler kepramukaan terhadap kedisiplinan siswa SD Negeri 4 Abuan. Untuk mendapatkan data yang akurat dalam penelitian ini menggunakan beberapa teknik pengumpulan data seperti: teknik observasi, dalam hal ini observasi difokuskan pada halhal yang berhubungan dengan variabel indikator yang telah ditentukan, yaitu ekstrakurikuler kepramukaan terhadap kedisiplinan siswa. Kedua yaitu teknik wawancara, pada penelitian ini wawancara dilakukan dengan guru dan siswa di SD Negeri 4 Abuan, Teknik wawancara ini bermaksud untuk mengecek dan membuktikan apakah responden mengisi kuisioner/angket dengan jujur atau tidak, dan penyebaran kuesioner/angket, Angket atau kuesioner merupakan teknik pengumpulan data yang dilakukan dengan cara memberi seperangkat pertanyaan atau pernyataan tertulis kepada responden untuk dijawab. Kuesioner dapat berupa pertanyaan tertutup atau terbuka, dapat diberikan kepada responden secara langsung atau dikirim melalui pos, atau internet (Sugiyono, 2015: 199). Pada penelitian ini, angket yang digunakan berbentuk skala likert dengan pernyataan bersifat tertutup yaitu jawaban atas pernyataan yang diajukan sudah disediakan, dengan alternatif pilihan 1 sampai dengan 4 jawaban pertanyaan dengan ketentuan sebagai berikut: (1) Selalu diberi skor 4, (2) Sering diberi skor 3, (3) Kadang-kadang diberi skor 2, dan (4) Tidak pernah diberi skor 1 .

$$
\text { Penilai secara kuantitatif }
$$
menggunakan skala interval dengan menginterpretasikan rata-rata skor menurut kategori penilaiannya. Interpretasi data yang diambil dari variabel ekstrakurikuler pramuka dan kedisiplinan siswa dibedakan menjadi lima kategori yaitu sangat jelek, jelek, cukup, baik, dan sangat baik. Interpretasi data tersebut sebagai berikut :

Rumus :

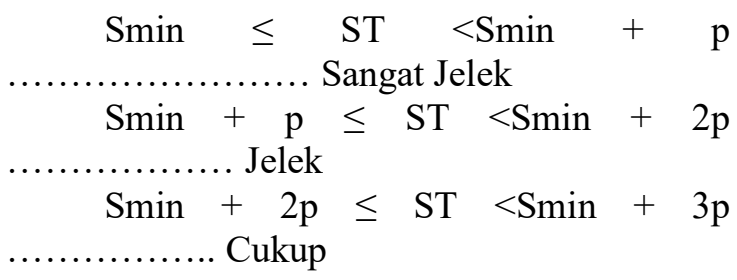


Smin
$\ldots \ldots \ldots \ldots \ldots$ Baik

Smin $+4 \mathrm{p} \leq \mathrm{ST} \quad<$ Smaks ................ Sangat Baik (Sundayana,

2015: 11)

Keterangan : ST : Skor Total

Smin : Skor Minimal

Smaks : Skor Maksimal

p : panjang kelas

Langkah-langkah yang dilakukan untuk membuat pengkategorian data ekstrakurikuler pramuka adalah sebagai berikut :

a. Menentukan Smaks = banyak butir pernyataan $\mathrm{x}$ skala tertinggi

b. Menentukan Smin = banyak butir pernyataan $\mathrm{x}$ skala terendah

c. Menentukan rentang $=$ skor maksimal skor minimal

d. Menentukan panjang kelas = rentang/ banyak kategori

Data yang diperoleh dari hasil penyebaran kuesioner dalam penelitian ini selanjutnya akan dianalisis dengan program SPSS (Statistical Package For Social Science) versi 25, adapun teknik analisis data yang digunakan yaitu : Uji Validitas, merupakan suatu ukuran yang menunjukkan ketepatan suatu instrument. Sugiyono (2015: 363) menjelaskan bahwa validitas merupakan derajad ketepatan antara data yang terjadi pada obyek penelitian dengan daya yang dapat dilaporkan oleh peneliti. Langkah-langkah pengujian validitas angket menurut Priyatno (2014: 52) yaitu klik Analyze - Correlate Bivariate. Pada kotak dialog Bivariate Correlations semua variabel dimasukkan ke kotak Variables, kemudian klik tombol $O k$. Pengujian validitas angket uji coba dilakukan kepada 25 siswa kelas IV dan V SD Negeri 1 Abuan, sehingga diketahui $\mathrm{n}=25$ maka $\mathrm{r}$ tabel pada taraf signifikansi 0.05 sebesar 0.396 . Kriteria pengambilan keputusan yaitu jika $r$ hitung > r tabel (uji 2 sisi dengan signifikansi 0.05), maka item dinyatakan valid. Namun, jika $r$ hitung $<r$ table (uji 2 sisi dengan signifikansi 0.05), maka item dinyatakan tidak valid (Priyatno, 2014: 55). Uji Releabilitas, Reliabilitas menunjuk pada satu pengertian bahwa sesuatu instrument cukup dapat dipercaya untuk digunakan sebagai alat pengumpul data karena instrument tersebut sudah baik (Arikunto, 2013: 221). Apabila datanya memang benar sesuai dengan kenyataannya, maka berapa kali pun diambil, tetap akan sama. Reliabel artinya dapat dipercaya, jadi dapat diandalkan. Langkahlangkah uji reliabilitas menurut Priyatno (2014:65) yaitu klik Analyze - Scale Reliability Analysis. Pada kotak dialog Reliability Analysis, masukkan item pada kotak items. Lalu klik tombol $O k$. Reliabel dapat diketahui pada nilai Cronbach's Alpha. Menurut Sekaran dalam Priyatno (2014: 66), reliabilitas kurang dari 0,6 adalah kurang baik, sedangkan 0,7 dapat diterima dan diatas 0,8 adalah baik. Perhitungan instrument ektrakurikuler pramuka didapatkan Cronbach's Alpha sebesar 0.860 (lampiran 8). Dapat diketahui bahwa data ekstrakurikuler pramuka dalam penelitian ini lolos uji reliabel. Sedangkan perhitungan instrument kedisiplinan siswa didapatkan Cronbach's Alpha sebesar 0.888 (lampiran 11). Dapat diketahui bahwa data kedisiplinan siswa dalam penelitian ini lolos uji reliabel. Dengan demikian angket dari kedua varibel dinyatakan valid dan reliabel sehingga dapat digunakan sebagai instrument dalam penelitian ini. Ada beberapa pengujian yang harus dijalankan terlebih dahulu untuk menguji apakah model yang dipergunakan tersebut mewakili atau mendekati kenyataan yang ada. Untuk menguji kelayakan model regresi yang digunakan, maka harus terlebih dahulu memenuhi uji asumsi klasik diantaranya uji Normalitas. Uji normalitas digunakan untuk mengetahui populasi data berdistribusi normal atau tidak. Langkah-langkahnya yaitu sebagai berikut: klik Analyze - Descriptive Statistics - Explore. Setelah kotak dialog Explore terbuka, lalu masukkan variabel ekstrakurikuler pramuka dan kedisiplinan siswa pada kotak Dependent List. Kemudian klik tombol Plots dan beri tanda centang pada Normality plot with test. Kemudian klik tombol continue. Selanjutnya, klik tombol $O k$. Hasil uji normalitas dapat 
dilihat pada output Test of Normality untuk metode Kolmogrov-Smirnov pada nilai sig. Data dinyatakan berdistribusi normal jika nilai signifikansi lebih besar dari 0.05. Jika nilai signifikansi lebih kecil dari 0.05, maka data tidak berdistribusi normal (Priyatno, 2014: 71).Uji berikutnya yaitu uji linieritas digunakan untuk melihat garis regresi antara $X$ (ekstrakurikuler pramuka) dan Y (kedisiplinan siswa) membentuk garis linier atau tidak (Sugiyono, 2011: 265). langkah-langkah menurut Priyatno (2014: 81) yaitu klik Analyze - Compare Means - Means. Setelah kotak dialog Means terbuka, masukkan variabel ekstrakurikuler pramuka pada kotak dependent list dan kedisiplinan siswa ke kotak independent list. Selanjutnya klik tombol Options. Pada kotak dialog Means, beri tanda centang pada Test for linearity pilih continue lalu klik tombol $O K$. Hasil uji linieritas dapat dilihat pada output ANOVA Table pada nilai signifikansi kolom Linearity. Dua variabel dikatakan memiliki hubungan linier apabila nilai signifikansinya kurang dari 0.05 . Selain itu, Hasil uji linieritas dapat dilihat pada output ANOVA Table pada nilai signifikansi kolom Deviation for Linearity. Jika nilai signifikansinya lebih dari 0.05 , maka kedua variabel terdapat hubungan yang linier. Analisi korelasi adalah analisis untuk mengukur keeratan hubungan secara linier antara dua variabel yang mempunyai distribusi data normal (Priyatno, 2014:123). langkah-langkah sebagai berikut: klikAnalyze - Correlate Bivariate. Setelah terbuka kotak dialog Bivariate Correlations, masukkan variabel ekstrakurikuler pramuka dan kedisiplinan siswa ke kotak Variabels. Kemudian klik $O k$. Nilai koefisien korelasi berkisar antara 0 sampui 1. Jika nilai koefisien pada Pearson Correlation mendekati 1, maka hubungan antara variabel independent dan variabel dependent adalah erat. Sebaliknya, jika nilai koefisien korelasi mendekati 0, maka hubungan semakin lemah.

Tabel 1. Interpretasi terhadap Koefisien Korelasi

\begin{tabular}{ll}
\hline \multicolumn{1}{c}{ Besarnya Nilai R } & \multicolumn{1}{c}{ Interpretasi } \\
\hline Antara 0.800 Sampai Dengan 1.00 & Sangat Kuat \\
Antara 0.600 Sampai Dengan 0.799 & Kuat \\
Antara 0.400 Sampai Dengan 0.599 & Sedang \\
Antara 0.200 Sampai Dengan 0.399 & Rendah \\
Antara 0.000 Sampai Dengan 0.199 & Sangat Rendah \\
\hline
\end{tabular}

Selain itu, adapun analisis data yang digunakan yaitu analisis regresi sederhana, Sugiyono (2011: 261) regresi sederhana didasarkan pada hubungan fungsional ataupun kausal satu variabel independen dengan satu variabel dependen. Dalam perhitungan analisis regresi sederhana peneliti menggunakan program SPSS versi 25 dengan langkahlangkah sebagai berikut: klik Analyze Regression - Linear. Setelah muncul kotak dialog Linear Regression, masukkan variabel ekstrakurikuler pramuka pada kotak Independent List dan kedisiplinan siswa pada kotak Dependent List lalu klik Statistics. Kemudianpada kotak Residuals beri tanda centang pada Durbin Watson lalu klik
Continue. Klik Plots lalu masukkan SRESID ke kotak Y dan ZPRED ke kotak X, kemudian beri tanda centang pada Normal Probality Plot. Selanjutnya, klik Continue sehingga kembali ke tampilan Linear Regression lalu klik $\mathrm{Ok}$ (Priyatno, 2014: 136). Selanjutnya, Uji Koefisien Determinasi (R2) Koefisien determinasi adalah kuadrat dari koefisien korelasi yang dikalikan dengan $100 \%$. Hal ini dilakukan untuk mengetahui seberapa besar variabel $\mathrm{X}$ mempunyai sumbangan atau ikut menentukan variabel Y. Untuk mengetahui seberapa pengaruh variabel $\mathrm{X}$ terhadap variabel Y yaitu dapat dilihat pada tabel Model Summary kolom $R$ Square. Kemudian angka tersebut diubah ke dalam bentuk persen 
(Priyatno, 2014: 142). Terakhir, Uji t Pengambilan keputusan tentang signifikansi pengaruh variabel $\mathrm{X}$ terhadap variabel $\mathrm{Y}$ dapat dilihat pada tabel (Coefficients) kolom $t$ hitung. Jika nilai $\mathrm{t}_{\text {hitung }}>$ nilai $\mathrm{t}_{\text {tabel, }}$, maka Ha diterima atau jika signifikansi $<0.05$, maka Ho ditolak. Artinya, ada pengaruh yang signifikan antara variabel $\mathrm{X}$ terhadap variabel $\mathrm{Y}$.

\section{HASIL DAN PEMBAHASAN}

Penelitian ini merupakan penelitian korelasi yang menggunakan dua variabel yaitu variabel ekstrakurikuler kepramukaan sebagai variabel bebas (X) dan variable kedisiplinan siswa sebagai variabel terikatnya (Y). Deskripsi data dari masing-masing variabel berdasarkan data yang diperoleh dari lapangan meliputi nilai mean (M), median (Me), modus (Mo), simpangan baku, skor terendah dan skor tertinggi. Data penelitian diperoleh dari siswa kelas II, III dan V SD Negeri 4 Abuan. Instrumen yang digunakan dalam variabel ini berbentuk angket tertutup yaitu : (1) Ekstrakurikuler Kepramukaan dalam penelitian ini diukur menggunakan angket yang terdiri dari 18 butir pernyataan positif maupun negatif yang telah diuji validitas dan reliabilitasnya dengan jumlah sampel 25 siswa. Angket memiliki 4 alternatif jawaban dimana skor tertinggi adalah 4, dan skor terendah adalah 1 . Data variabel ekstrakurikuler kepramukaan diperoleh nilai mean sebesar 80.13; modus sebesar 82; median sebesar 82; dan simpangan baku sebesar 6.68; dengan skor tertinggi 90 dan skor terendah 60. Kegiatan ekstrakurikuler kepramukaan siswa SD Negeri 4 Abuan yang termasuk dalam kategori sangat baik $(68 \%)$ dengan jumlah siswa 17 , kategori baik $(28 \%)$ dengan jumlah siswa 7 , kategori cukup (4\%) dengan jumlah siswa 1, kategori jelek $(0 \%)$ kategori sangat jelek (0\%). Dengan demikian dapat disimpulkan bahwa tingkat keaktifan mengikuti kegiatan ekstrakurikuler kepramukaan siswa SD Negeri 4 Abuan termasuk dalam kategori sangat baik; (2) Kedisiplinan Siswa alam penelitian ini diukur menggunakan angket yang terdiri dari 20 butir pernyataan positif maupun negatif yang telah diuji validitas dan reliabilitasnya dengan jumlah responden 25 siswa angket memiliki 4 alternatif jawaban dimana skor tertinggi adalah 4, dan skor terendah adalah 1. Data variabel kedisiplinan siswa diperoleh nilai mean sebesar 81.30; modus sebesar 85; median sebesar 80; dan simpangan baku sebesar 8.89; dengan skor tertinggi 98 dan skor terendah 61 . Kedisiplinan siswa SD Negeri 4 Abuan yang termasuk dalam kategori sangat baik (36\%) dengan jumlah siswa 9, kategori baik (56\%) dengan jumlah siswa 14, kategori cukup (8\%) dengan jumlah siswa 2, kategori jelek (0\%), dan kategori sangat jelek (0\%) (lampiran 20). Dengan demikian dapat disimpulkan bahwa kedisiplinan siswa SD Negeri 4 Abuan termasuk dalam kategori baik.

Uji normalitas dilakukan untuk mengetahui nilai residual yang dihasilkan dari regresi berdistribusi normal atau tidak. Apabila data berdistribusi normal, analisis untuk menguji hipotesis dapat dilakukan. Dikatakan normal jika nilai signifikansi lebih besar dari 0.05, dan sebaliknya. Pengujian normalitas data pada penelitian ini menggunakan uji normalitas dengan metode uji Lilliefors dengan bantuan program SPSS versi 25. Dengan taraf signifikansi 5\% hasil uji Kolmogorov-Smirnov dapat dilihat pada tabel 2 sebagai berikut:

Tabel 2. Hasil Uji Normalitas

\begin{tabular}{|c|c|c|c|c|c|c|}
\hline \multicolumn{7}{|l|}{ Tests of Normality } \\
\hline Variabel & Statistic & $\mathrm{df}$ & Sig. & Statistic & df & Sig. \\
\hline Ekstrakurikuler Pramuka & 0.129 & 25 & 0.200 & 0.931 & 25 & 0.092 \\
\hline $\begin{array}{l}\text { Kedisiplinan Siswa } \\
\text { a. Lilliefors Significance }\end{array}$ & $\begin{array}{l}0.141 \\
\text { rection }\end{array}$ & 25 & 0.200 & 0.962 & 25 & 0.452 \\
\hline
\end{tabular}


Hasil pada tabel 02 diketahui data ekstrakurikuler kepramukaan diperoleh nilai Signifikansi (0.200) > 0.05, dapat diartikan data ekstrakurikuler kepramukaan berdistribusi normal. Sedangkan data kedisiplinan siswa diperoleh nilai Signifikansi (0.200) > 0.05, dapat diartikan data kedisiplinan siswa berdistribusi normal. Dengan demikian dapat disimpulkan bahwa sebaran data dari kedua variabel tersebut berdistribusi normal atau memenuhi persyaratan uji normalitas. Uji lineritas dimaksudkan untuk mengetahui pola hubungan antara variabel bebas dengan variabel terikat apakah berbentuk linear atau tidak. Data diolah dengan bantuan program SPSS versi 25 dengan menggunakan Test for Linearity pada taraf signifikansi 0.05. Dua variabel dikatakan mempunyai hubungan yang linier bila nilai signifikansi (Linearity) lebih kecil dari taraf signifikansi 0.05. Sebaliknya jika nilai signifikansi (Linearity) lebih besar dari taraf signifikansi 0.05 , maka hubungan antara variabel bebas dan variabel terikat tidak linear. Hasil uji linearitas dapat dilihat pada tabel sebagai berikut:

Tabel 3. Hasil Uji Linieritas

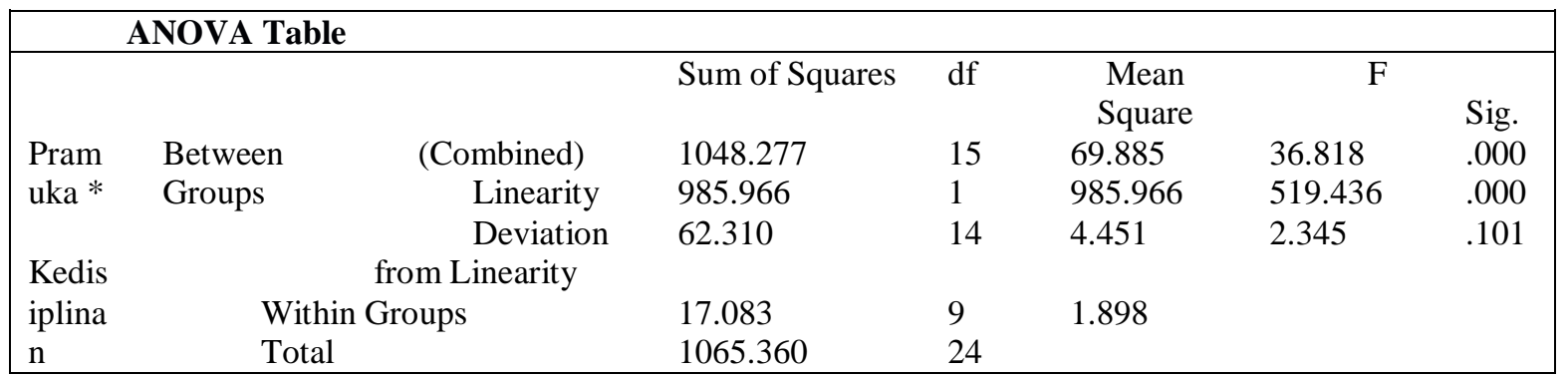

Berdasarkan hasil analisi pada tabel 3 dapat diketahui bahwa nilai signifikansi pada Linearity sebesar 0.000 . Nilai tersebut lebih kecil dari pada taraf signifikansi yang ditentukan, yaitu sebesar 0.05. Jadi dapat disimpulkan bahwa hubungan variabel ekstrakurikuler kepramukaan dengan variabel kedisiplinan siswa adalah linier. Pengujian hipotesis dilakukan untuk membuktikan benar tidaknya hipotesis yang diajukan, karena pada dasarnya hipotesis merupakan pernyataan yang masih lemah kebenarannya atau dugaan yang sifatnya sementara. Pengujian hipotesis dalam penelitian ini menggunakan analisis korelasi, regresi sederhana, dan koefisien determinasi serta uji t. Adapun hipotesis yang diuji adalah sebagai berikut: $\mathrm{Ha}$ : "Terdapat pengaruh ekstrakurikuler kepramukaan terhadap kedisiplinan siswa SD Negeri 4 Abuan"; Ho : "Tidak terdapat pengaruh ekstrakurikuler kepramukaan terhadap kedisiplinan siswa SD Negeri 4 Abuan". Koefisien korelasi dicari untuk menguji hipotesis dengan melihat seberapa besar pengaruh ekstrakurikuler kepramukaan $(\mathrm{X})$ terhadap kedisiplinan siswa (Y).

Tabel 4. Hasil Analisis Korelasi

\begin{tabular}{|cccc|}
\hline Correlations & & Pramuka & Kedisiplinan \\
Pramuka $(\mathrm{X})$ & Pearson Correlation & 1 & $.962^{* *}$ \\
& Sig. (2-tailed) & & .000 \\
& N & 25 & 25 \\
Kedisiplinan (Y) & Pearson Correlation & $.962^{* *}$ & 1 \\
\hline
\end{tabular}




\begin{tabular}{ccc|} 
Sig. (2-tailed) & .000 \\
$\mathrm{~N}$ & 25 & 25 \\
$* *$. Correlation is significant at the 0.01 level (2-tailed). & \\
\hline
\end{tabular}

Berdasarkan analisis yang telah dilakukan dengan menggunakan bantuan program SPSS versi 25, didapatkan koefisien korelasi antara ekstrakurikuler kepramukaan terhadap kedisiplinan siswa sebesar 0.962 . Analisis regresi sederhana merupakan salah satu metode untuk menentukan hubungan sebab akibat antara satu variabel dengan variabel lain. Analisis regresi digunakan untuk melakukan prediksi seberapa besar nilai variabel dependen apabila terjadi manipulasi atau perubahan nilai variabel independen. Analisis regresi ini dapat digunakan untuk mengetahui pengaruh ekstrakurikuler kepramukaan (Variabel $\mathrm{X}$ ) terhadap kedisiplinan siswa (Variabel Y).

Tabel 5. Hasil Analisis Regresi Linier Sederhana

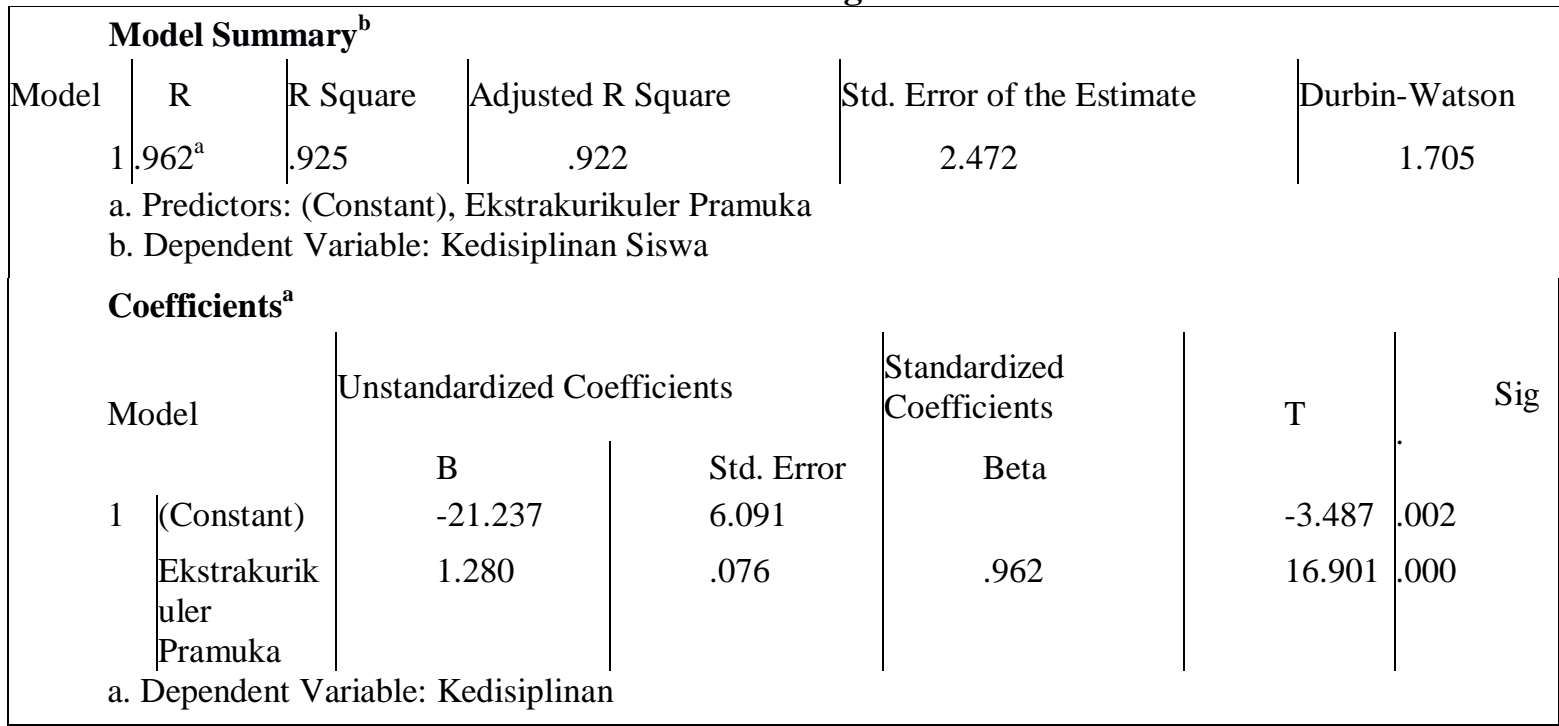

Tabel analisis tersebut menunjukkan bahwa penelitian ini memperoleh koefisien determinan (R2) sebesar 0.925 yang menandakan bahwa factor ekstrakurikuler kepramukaan memberikan kontribusi terhadap munculnya kedisiplinan siswa sebesar 9.25\%, sedangkan $7.5 \%$ dipengaruhi oleh faktor-faktor lain yang tidak diteliti dalam penelitian ini.

Persamaan garis regresi pada hasil perhitungan analisis table 05 menunjukkan bahwa penelitian ini memperoleh nilai konstan sebesar 21.237 sedangkan koefisien garis regresinya sebesar 1.280. Dengan demikian persamaan regresinya dapat dituliskan sebagai berikut:

$$
\mathrm{Y}=21.237+1.280 \mathrm{X}
$$
siswa

Keterangan: $\quad \mathrm{Y}=$ Kedisiplinan

$\mathrm{X}=$ Ekstrakurikuler Pramuka

Artinya:

Nilai 1.280 ialah perubahan garis regresi, dimana setiap satu satuan dari nilai $X$ akan diikuti perubahan nilai $\mathrm{Y}$ sebesar 1.280. Maksud pernyataan tersebut adalah bahwa setiap kenaikan 1 unit nilai ekstrakurikuler kepramukaan maka akan diikuti kenaikan nilai kedisiplinan siswa sebesar 1.280 dengan asumsi bahwa ekstrakurikuler kepramukaan bersifat tetap.

Uji t merupakan uji hipotesis untuk mengetahui apakah variabel $\mathrm{X}$ berpengaruh terhadap variabel Y. Menentukan ada tidaknya 
pengaruh ekstrakurikuler kepramukaan terhadap kedisiplinan siswa dapat dilakukan dengan cara membandingkan nilai t-hitung dengan t-tabel. Jika nilai t-hitung $>\mathrm{t}$-tabel dan signifikansi $<0.05$ maka Ha diterima, dan Ho ditolak.

Berdasarkan hasil perhitungan uji $t$ maka diperoleh nilai t-hitung sebesar 16.901, ttabel sebesar 2.059 dan signifikansi 0.000 . Karena $16.901>2.059$ dan $0.000<0.05$ maka Ho ditolak dan Ha diterima. Dengan demikian, dapat disimpulkan bahwa terdapat pengaruh antara ekstrakurikuler kepramukaan yang signifikan terhadap kedisiplinan siswa SD Negeri 4 Abuan.

Hasil penelitian membuktikan bahwa ekstrakurikuler pramuka berpengaruh signifikan terhadap kedisiplinan siswa. Dalam penelitian ini yang menjadi variabel bebas adalah ekstrakurikuler pramukadan yang menjadi variable terikatnya adalah kedisiplinan siswa. Dengan adanya pengaruh positif tersebut, maka dapat diartikan jika tingkat ekstrakurikuler pramuka mengalami perubahan tidak menutup kemungkinan kedisiplinan siswa juga akan mengalami perubahan. Hal ini sejalan dengan pendapat Gunawan $(2014,265)$ tentang kepramukaan merupakan proses pendidikan di luar lingkungan sekolah dan di luar lingkungan keluarga dalam bentuk kegiatan menarik, menyenangkan, sehat, teratur, terarah, praktis yang dilakukan di alam terbuka yang sasaran akhirnya adalah untuk pembentukan watak, akhlak, dan budi pekerti luhur.

Ekstrakurikuler kepramukaan dapat dijadikan sebagai sarana menumbuhkan kedisiplinan siswa. Siswa yang selalu aktif mengikuti ekstrakurikuler kepramukaan dirinya akan menyerap nilai-nilai disiplin yang terkandung didalamnya. Antara lain adalah nilai-nilai bagaimana mengatur waktu secara efektif dan efisien, menghargai orang lain, mengatur kekompakan dengan kelompoknya, menghargai dan mencintai alam semesta serta mencintai sesame hidup, sikap patuh terhadap pembina serta sikap berpetualangan yang menantang dan menggembirakan.
Materi-materi yang diajarkan dalam kepramukaan sangat mendukung terbentuknya sikap disiplin di sekolah. Karena sikap dan tingkah laku pramuka dalam mengikuti ekstrakurikuler pramuka dibentuk melalui dasa darma yang berisi sepuluh macam pedoman bertingkah laku bagi seorang pramuka. Untuk mengarah pada sikap disiplin yang baik maka pramuka biasanya mengacu pada dasa darma ke delapan yang berbunyi "disiplin, berani, setia". Artinya bahwa seorang pramuka harus berusaha untuk mengendalikan dan mengatur diri, menaati peraturan, menjalani ajaran dari ibadah agama, belajar untuk menilai kenyataan, bukti, dan kebenaran suatu keterangan (informasi), dan patuh dengan pertimbangan dan keyakinan.

Kepramukaan mengajarkan kedisiplinan dibiasakan melalui berbagai hal diantaranya adalah mengikuti upacara saat latihan rutin ekstrakurikuler pramuka dan baris berbaris. Kedisiplinan ini dibiasakan agar peserta didik menjadikan sikap disiplin sebgai bagian dari dirinya bukan paksaan dari orang lain. Baden Powel dalam Rahmanita (2015) menegaskan bahwa sikap disiplin adalah harus timbul dari dalam hati dan bukan dipaksakan oleh orang lain, disiplin sangat penting dalam rangka membangun masyarakat, karena kemakmuran didapat melalui disiplin yang tinggi. Perhitungan analisis regresi linier sederhana diperoleh koefisien korelasi (R) sebesar 0.962. Hal tersebut menunjukkan bahwa besarnya pengaruh ekstrakurikuler pramuka terhadap kedisiplinan siswa tergolong sedang. sedangkan R-Square sebesar 0.925 yang berarti bahwa ekstrakurikuler pramuka memberikan kontribusi terhadap kedisiplinan siswa sebesar $92.52 \%$ dan selebihnya dipengaruhi oleh faktor lain yang tidak diteliti dalam penelitian ini.Persamaan garis regresi pada penelitian ini memperoleh nilai konstan sebesar 21.237 dengan koefisien regresi untuk variabel ekstrakurikuler pramuka sebesar 1.280. Sehingga persamaan regresi dapat dinyatakan bahwa $\mathrm{Y}=21.237+2.280 \mathrm{X}$. Hal ini berarti bahwa setiap kenaikan 1 unit skor ekstrakurikuler pramuka maka akan diikuti 
kenaikan kedisiplinan siswa sebesar 1.280 dengan asumsi ekstrakurikuler pramuka bersifat tetap. Nilai t-hitung sebesar 16.901, ttabel sebesar 2.976 dan signifikansi 0.000 . Karena $16.959>2.976$ dan $0.000<0.05$ maka Ho ditolak dan $\mathrm{Ha}$ diterima. Dapat disimpulkan bahwa terdapat pengaruh ekstrakurikuler pramuka terhadap kedisiplinan siswa SD Negeri 4 Abuan Kecamatan Susut Kabupaten Bangli.

\section{SIMPULAN DAN REKOMENDASI}

Berdasarkan hasil analisis data dan pembahasan, maka kesimpulan yang dapat diambil adalah sebagai berikut:

Hasil perhitungan diperoleh nilai thitung sebesar 16.901, t-tabel sebesar 2.976 dan signifikansi 0.000. Karena $16.901>2.976$ dan $0.000<0.05$ sehingga Ha diterima, yang berarti bahwa terdapat pengaruh yang signifikan antara ekstrakurikuler kepramukaan terhadap kedisiplinan siswa SD Negeri 4 Abuan Kecamatan Susut Kabupaten Bangli. Besarnya pengaruh yang signifikan ektrakurikuler kepramukaan terhadap kedisiplinan siswa tergolong tinggi dengan koefisien korelasi 0.925. Besar kecilnya kedisiplinan siswa SD Negeri 4 Abuan Kecamatan Susut Kabupaten Bangli, dapat diprediksi melalui besarnya skor ekstrakurikuler kepramukaan dengan persamaan regresi $\mathrm{Y}=21.237+2.280 \mathrm{X}$. ontribusi pengaruh variabel ekstrakurikuler pramukasebesar $92.5 \%$ terhadap kedisiplinan siswa dan sisanya $7.5 \%$ dipengaruhi oleh faktor-faktor lain yang tidak diteliti dalam penelitian ini.

\section{DAFTAR PUSTAKA}

Aqib, Z. (2012). Pendidikan Karakter di Sekolah Membangun Karakter dan Kepribadian Anak. Bandung: Yrama Widya.

Aqib, Z. (2014). Ikhtisar Bimbingan dan Konseling di Sekolah. Bandung:Yrama Widya.

Arikunto, S. (2013). Prosedur Penelitian, Suatu Pendekatan Praktik. Jakarta: Asdi Mahasatya.

Asmani, J. M. (2013). Buku Panduan Internalisasi Pendidikan Karakter di Sekolah (Cetakan VI). Jogjakarta: Diva Press.

Daryanto., dan Suryatri, D. (2013). Implementasi Pendidikan Karakter di Gunawan, Heri. 2014. Pendidikan Karakter, Konsep dan Implementasi. Bandung: Alfabeta.

Priyatno, D. (2014). SPSS 22 Pengolah Data Terpraktis. Yogyakarta: Andi Yogyakarta.

Rahmatika, D. (2015). Buku Pintar Pramuka Edisi Pelajar. Jakarta: Bee Media Pustaka.

Sugiyono. (2011). Statistika untuk Penelitian. Bandung: Alfabeta.

Sugiyono. (2015). Metode Penelitian Pendidikan. Bandung: Alfabeta.

Wiyani, N. A. (2013). Konsep, Praktik, \& Strategi Membumikan Pendidikan Karakter di SD. Jogjakarta: Ar-Ruzz Media.

Wiyani, N. A. (2014). Manajemen Kelas: Teori dan Aplikasi untuk Menciptakan Kelas yang Kondusif. Jogjakarta: ArRuzz Media. 